PRACE NAUKOWE UNIWERSYTETU EKONOMICZNEGO WE WROCLAWIU

Wyzwania dla spójności Europy -

ISSN 1899-3192

społeczeństwo, granice, solidarność

e-ISSN 2392-0041

\title{
Renata Bielak
}

Główny Urząd Statystyczny w Warszawie

e-mail: r.bielak@stat.gov.pl

\section{ZWIĘKSZANIE WZROSTU GOSPODARCZEGO \\ I ZATRUDNIENIA JAKO WYZWANIE DLA SPÓJNOŚCI UNII EUROPEJSKIEJ}

\section{IMPROVEMENT OF ECONOMIC GROWTH AND EMPLOYMENT AS A CHALLENGE FOR THE EUROPEAN UNION COHESION}

DOI: $10.15611 /$ pn.2017.465.03

JEL Classification: E60, J01, O11

Streszczenie: Pięcioletni okres funkcjonowania strategii Europa 2020 wskazuje, że kryzys miał znaczny wpływ na postęp w osiąganiu uzgodnionych celów. W warunkach utrudniających realizację założeń strategii podjęto decyzję o ukierunkowaniu funduszy europejskich na działania wspierające umocnienie rynków pracy i gospodarek krajów członkowskich. Podstawowym narzędziem służącym pobudzaniu wzrostu i zatrudnienia jest polityka spójności. Celem artykułu jest wskazanie aktualnego stanu realizacji strategii Europa 2020, ze szczególnym uwzględnieniem rozwoju gospodarczego i sytuacji na rynku pracy krajów Wspólnoty oraz miejsca Polski w UE. Zróżnicowana dynamika gospodarcza oraz problemy z bezrobociem dotykające wiele państw skłoniły decydentów do weryfikacji obszarów interwencji i większej koncentracji polityki spójności. Inwestycje na rzecz wzrostu gospodarczego i zatrudnienia uznano za warunek konieczny dla osiągnięcia celów unijnej strategii.

Słowa kluczowe: Europa 2020, wzrost gospodarczy, rynek pracy.

Summary: Five years after the implementation of Europe 2020 strategy it is evident that the crisis influenced significantly the process of achieving the goals. In the view of these difficult conditions the decision about focusing European funds on activities improving labour market and national economies was taken. The key instrument supporting economic growth and employment is cohesion policy. The article presents the progress made so far in the implementation of Europe 2020 goals, especially in the scope of economic growth and labour market. There is analysed the situation in the EU as well as the position of Poland among member states. Differences in economic growth rates and unemployment related problems got decision-makers to the verification of intervention areas and improved the concentration of cohesion policy. Investments made on economic growth and employment were recognised as necessary conditions for reaching the European strategy goals.

Keywords: Europe 2020, economic growth, labour market. 


\section{Wstęp}

W 2010 r. przywódcy unijni przyjęli strategię Europa 2020, która określa wizję rozwoju społeczno-gospodarczego Unii Europejskiej na aktualne dziesięciolecie. Szczególny czas opracowywania strategii spowodował, że ten unijny program był tworzony jako odpowiedź na kryzys gospodarczy. W dokumencie uwzględniono jednocześnie długofalowe wyzwania stojące przed Europą, związane m.in. z globalizacją, starzeniem się społeczeństw oraz rosnącą potrzebą racjonalnego wykorzystywania zasobów. Pierwsze lata wdrażania strategii pokazały, że kryzys poważnie wpłynął na gospodarkę europejską i odsłonił jej strukturalne słabości, ograniczając tym samym możliwości sprawnej realizacji założonych celów. W tych okolicznościach istotne było wzmożenie wysiłków i konsekwentne podejmowanie działań na rzecz wzrostu inteligentnego, zrównoważonego i sprzyjającego włączeniu społecznemu. Jako potwierdzenie determinacji w pokonywaniu skutków kryzysu i dążeniu do wzrostu gospodarczego, w 2012 r. został przyjęty Pakt na rzecz wzrostu gospodarczego i zatrudnienia.

Skala działań podejmowanych przez kraje na rzecz realizacji celów strategicznych jest uzależniona od dostępności środków finansowych. Stąd w nowym okresie programowania polityka spójności została wskazana jako podstawowy instrument wsparcia strategii Europa 2020.

Systematyczne monitorowanie stanu realizacji założonych celów jest niezbędne dla podejmowania decyzji dotyczących kierunków interwencji czy wydatkowania środków finansowych. Celem artykułu jest zobrazowanie sytuacji na półmetku okresu wdrażania strategii. Ocena postępów została dokonana w oparciu o analizę zmian w czasie podstawowych wskaźników strategii Europa 2020, ustanowionych przez Komisję Europejską. Ogólne założenia dotyczące pobudzania wzrostu i zatrudnienia oraz nowej polityki spójności zostały przedstawione w pierwszej części pracy. Druga część dotyczy sytuacji w Unii Europejskiej w dotychczasowym okresie obowiązywania strategii Europa 2020, ze wskazaniem aktualnego stanu wdrażania jej celów.

\section{Działania na rzecz wzrostu gospodarczego i zatrudnienia}

Podejmując wyzwanie wydźwignięcia Europy z kryzysu, przywódcy unijni zdecydowali o reformie zarządzania gospodarczego we Wspólnocie. W rezultacie wprowadzono konkretne regulacje i mechanizmy, których celem jest wzmacnianie koordynacji polityki gospodarczej i zapobieganie nierównowagom makroekonomicznym. Przyjęte procedury i rozwiązania prawne, służące przede wszystkim zapewnieniu dyscypliny fiskalnej, stanowią jeden z dwóch filarów kompleksowego planu rozwojowego dla Europy. Za drugi warunek, niezbędny do osiągnięcia trwałego rozwoju, uznano wdrażanie działań pobudzających wzrost gospodarczy i sprzyjających tworzeniu nowych miejsc pracy. Całościowa wizja współpracy dla osiągnięcia rozwoju 
została przedstawiona w Pakcie na rzecz wzrostu gospodarczego i zatrudnienia (2012), przyjętym przez szefów państw i rządów podczas szczytu Rady Europejskiej w czerwcu 2012 r. Pakt podkreśla rolę polityk europejskich we wdrażaniu uzgodnionych przedsięwzięć. Wśród priorytetów wymieniono: usprawnienie zarządzania jednolitym rynkiem, rozwijanie unijnego rynku internetowego i rynku energii, zmniejszanie obciążeń administracyjnych, uzgodnienie polityki podatkowej. Szczególne znaczenie przypisano innowacyjności, która służy wzmacnianiu konkurencyjności gospodarki. Aby wspierać innowacje, kraje powinny zadbać o nakłady na badania i rozwój oraz wdrażać rozwiązania, które pozwolą na szybkie uzyskiwanie efektów z ponoszonych nakładów. Warunki do prowadzenia działalności badawczej będą przesądzały o tempie rozwoju innowacji, a w rezultacie o zdolności do kreowania wzrostu gospodarczego.

Zapewnienie dobrobytu społecznego wymaga podejmowania inicjatyw dotyczących rynku pracy. Zagrożenie bezrobociem, w szczególności dotkliwie oddziaływujące na ludzi młodych, jest jednym z najpoważniejszych i najpilniejszych problemów do rozwiązania. Wysiłki powinny być więc koncentrowane na tworzeniu nowych miejsc pracy, reformach rynku pracy i inwestycjach w kapitał ludzki, służących zwiększaniu zatrudnienia. W Pakcie zwrócono również uwagę na potrzebę poprawy mobilności pracowników w ramach rynku UE.

Podjęcie decyzji w sprawie przyjęcia Paktu oznacza potwierdzenie roli strategii Europa 2020 jako nadrzędnego dokumentu wskazującego kierunki rozwoju i cele UE. Obok katalogu działań wspierających wzrost gospodarczy i zatrudnienie, w Pakcie uwzględniono instrumenty finansowe wspomagające realizację zamierzonych celów. Pobudzaniu gospodarki ma służyć pula środków wyodrębniona w ramach funduszy Europejskiego Banku Inwestycyjnego. Ważną zapowiedzią było również ukierunkowanie wieloletnich ram finansowych na zadania i inwestycje sprzyjające priorytetowym działaniom, których efekty będą zgodne ze strategią $E u$ ropa 2020. Zasadniczą rolę w inwestowaniu na rzecz wdrażania celów strategii przypisano polityce spójności.

Cel polityki spójności, określony w Traktacie UE, wskazuje na zmniejszanie dysproporcji w rozwoju społecznym, gospodarczym i terytorialnym regionów. Przy utrzymaniu aktualności tego założenia, w miarę czasu zmieniało się ukierunkowanie priorytetów polityki spójności. Zgodnie z założeniem wsparcia strategii Europa 2020, obszary interwencji w perspektywie finansowej 2014-2020 zostały ograniczone i powiązane z celami dotyczącymi zatrudnienia, badań i rozwoju, klimatu i energii, edukacji oraz walki z ubóstwem i wykluczeniem społecznym. Sposób funkcjonowania polityki spójności jest zbieżny z obowiązującymi mechanizmami zarządzania gospodarczego we Wspólnocie, a planowane inwestycje uwzględniają coroczne zalecenia Komisji dla poszczególnych krajów członkowskich. W ten sposób jest urzeczywistniany proces kompleksowej koordynacji polityki rozwoju UE. 


\section{Unia Europejska na pólmetku realizacji strategii Europa 2020}

\subsection{Spowolnienie wzrostu gospodarczego}

W okresie uzgadniania strategii Europa 2020 gospodarka UE była w trudnej sytuacji. Kryzys gospodarczy wyzwolił szereg problemów, które negatywnie oddziaływały na rozwój gospodarczy i społeczny. Produkt krajowy brutto (PKB) w 2009 r. był mniejszy niż w roku poprzednim o 4,4\%. Po niewielkim wzroście w dwóch następnych latach, w 2012 r. ponownie odnotowano spadek PKB. Od 2013 r. obserwowane jest stopniowe ożywienie koniunktury gospodarczej w UE.

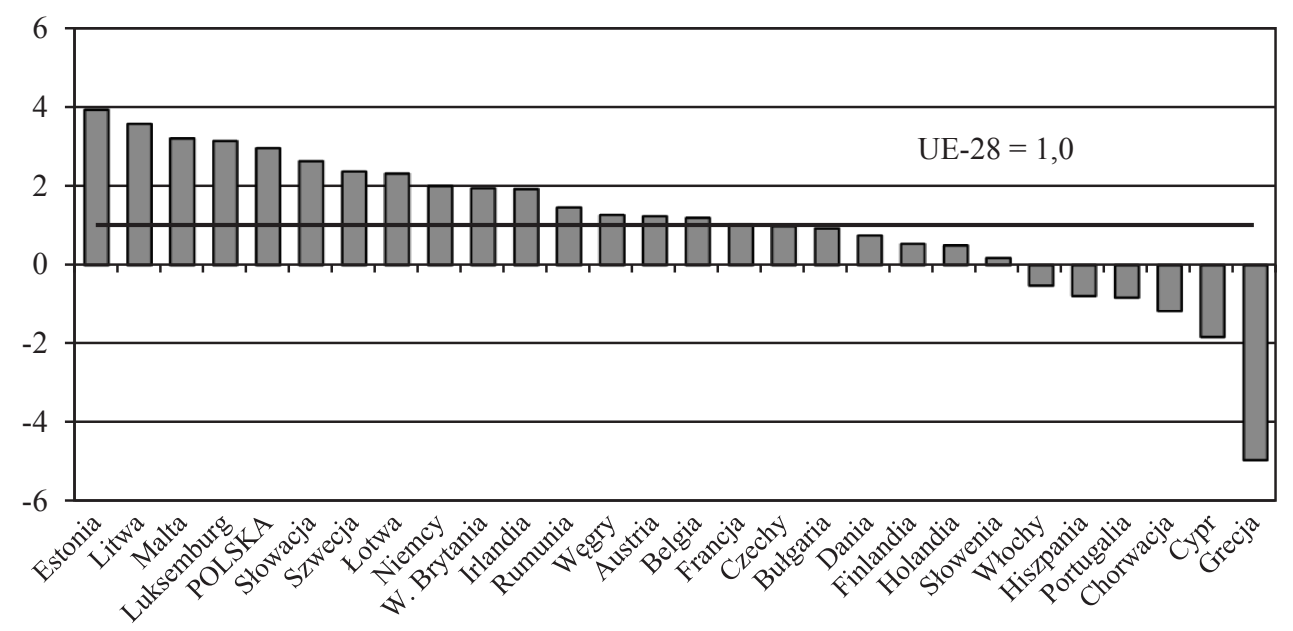

Rys. 1. Średnie tempo wzrostu PKB w latach 2010-2014 (w \%)

Źródło: opracowanie własne na podstawie danych bazy Eurostat.

Średnie tempo wzrostu gospodarczego w UE w okresie 2010-2014 wyniosło $1,0 \%$. Analizując sytuację w poszczególnych gospodarkach, widać dość duże zróżnicowanie dynamiki PKB pomiędzy krajami. Najwyższy wzrost gospodarczy notowano w Estonii (3,9\%) i na Litwie (3,6\%). W sześciu krajach UE obserwowano spadek PKB w analizowanym okresie, największy w Grecji. Polska, ze średnim wzrostem PKB o 3,0\%, uplasowała się na piątym miejscu wśród krajów o najwyższej dynamice gospodarczej i była jedynym krajem UE, który nie odnotował recesji $\mathrm{w}$ żadnym $\mathrm{z}$ analizowanych lat. Łagodzący wpływ na tę sytuację miały środki z funduszy europejskich, których Polska jest największym beneficjentem netto. Według szacunków Ministerstwa Infrastruktury i Rozwoju [Wpływ członkostwa Polski... 2014, s. 21], w 2012 r. blisko połowa wzrostu gospodarczego w Polsce była generowana przez przedsięwzięcia współfinansowane ze środków UE. 


\subsection{Zagrożenie bezrobociem}

Sytuacja na rynku pracy w dotychczasowym okresie wdrażania strategii Europa 2020 pozostawała pod wpływem kryzysu. Stopa bezrobocia w UE w 2009 r. wynosiła 9,0\% i zwiększała się w kolejnych latach, do 10,9\% w 2013 r. Po pięciu latach wzrostu, w 2014 r. stopa bezrobocia zaczęła się obniżać i w 2015 r. spadła do 9,4\%. Najwyższe bezrobocie (powyżej 20\%) utrzymuje się w Grecji i Hiszpanii. W Polsce tendencje były zbieżne z obserwowanymi w UE; stopa bezrobocia kształtowała się poniżej średniej unijnej i w 2015 r. wyniosła 7,5\%.

Poważnym problemem jest wysokie bezrobocie wśród ludzi młodych, którzy rozpoczynają aktywność na rynku pracy. Stopa bezrobocia osób młodych (poniżej 25 roku życia) jest znacznie wyższa niż stopa bezrobocia ogółem - w 2015 r. wynosiła 20,4\% dla UE (tj. wartość zbliżona do notowanej w 2009 r. i mniejsza niż w poprzednich pięciu latach). Najwyższy poziom stopy bezrobocia młodzieży (sięgający 50\%) występuje w Grecji, Hiszpanii i Chorwacji. Na drugim biegunie znajdują się Niemcy, gdzie stopa bezrobocia osób młodych systematycznie spadała w kolejnych latach i w 2015 r. wyniosła 7,3\%. W Polsce odsetek osób młodych pozostających bez pracy waha się na poziomie średniej dla Wspólnoty i podobnie jak w UE, po wzroście w okresie 2009-2013, w ostatnich dwóch latach obserwowana jest tendencja spadkowa.

Szczególnej uwagi wymaga narastające bezrobocie długookresowe, które istotnie wpływa na zagrożenie ubóstwem. Odsetek osób długotrwale bezrobotnych (tj. poszukujących pracy przez minimum rok) wśród bezrobotnych w UE wynosił

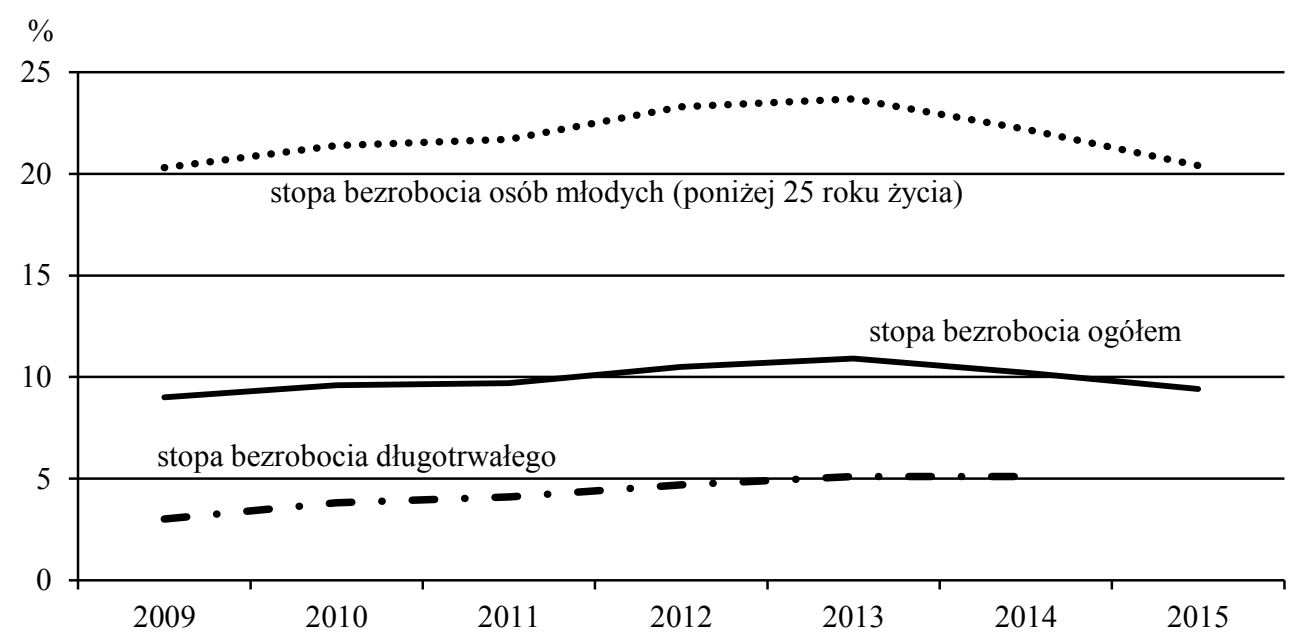

Rys. 2. Stopa bezrobocia w Unii Europejskiej

Źródło: opracowanie własne na podstawie danych bazy Eurostat. 
w 2014 r. blisko 50\%, podczas gdy w 2009 r. stanowił ok. 33\%. Stopa bezrobocia długotrwałego zwiększyła się w okresie 2009-2014 z 3,0\% do 5,1\%. Problem trwałego bezrobocia dotyka państw członkowskich w różnym stopniu. Najkorzystniejszą sytuację mają kraje skandynawskie, Austria, Niemcy i Wielka Brytania, gdzie stopa bezrobocia długookresowego kształtuje się na poziomie 1-2\%. Zupełnie inna skala zagrożenia trwałym bezrobociem rysuje się w Grecji (stopa bezrobocia długotrwałego blisko 20\%), Hiszpanii czy Chorwacji (powyżej 10\%). Polska należy do grupy krajów o niższej niż przeciętnie w UE stopie bezrobocia długotrwałego - 3,8\% w $2014 \mathrm{r}$.

\subsection{Stan realizacji celów strategii Europa 2020}

W ramach trzech obszarów priorytetowych strategii Europa 2020 przywódcy unijni wyznaczyli pięć celów nadrzędnych, które mają być osiągnięte do roku 2020 na poziomie UE. Kraje członkowskie zostały zobowiązane do przełożenia celów unijnych na cele krajowe oraz do przygotowania planu ich realizacji. Postępy we wdrażaniu zamierzeń podlegają corocznej analizie na podstawie ustalonego zbioru wskaźników przypisanych do poszczególnych celów.

- Zwiększanie zatrudnienia (cel - wzrost wskaźnika zatrudnienia osób w wieku 20-64 lata do minimum 75\%)

Efektywny rynek pracy wpływa na rozwój gospodarczy oraz ma kluczowe znaczenie dla wzmacniania spójności społecznej. Obserwowana stagnacja zatrudnienia jest stopniowo eliminowana, ale osiągnięcie konkretnych zmian wymaga czasu. W 2014 r. wskaźnik zatrudnienia we Wspólnocie był wyższy niż w poprzednich pięciu latach i wyniósł 69,2\% (tj. o 0,2 pp. więcej niż w 2009 r.). W większości krajów (w tym w Polsce) obserwowano poprawę w stosunku do 2009 r. Osiągnięcie celu zakładanego na poziomie UE, jak i wielu państw członkowskich, jest jednak dużym wyzwaniem. W Polsce wskaźnik zatrudnienia zwiększył się w okresie 2009-2014 z 64,9\% do 66,5\% (wartość docelowa przyjęta na 2020 r. wynosi 71\%). Realizacja tego celu jest trudna i zależna od kształtowania polityki rynku pracy w najbliższych latach. Szczególnej uwagi wymaga m.in. aktywizacja zawodowa kobiet, dla których wskaźnik zatrudnienia jest znacznie niższy niż wśród mężczyzn.

- Inwestowanie w badania i rozwój (cel - wzrost nakładów na B+R do 3\% PKB)

Inwestowanie $\mathrm{w}$ wiedzę $\mathrm{i}$ innowacje to podstawowe założenie pobudzania wzrostu inteligentnego. Dotychczasowe postępy w tym obszarze nie wyglądają imponująco - nakłady na działalność B+R stanowiły w 2014 r. 2,03\% unijnego PKB. To odsetek wyższy w porównaniu z 2009 r., ale tempo zmian jest niewielkie. Największy udział nakładów na badania i rozwój w PKB mają kraje skandynawskie. Finlandia i Szwecja ustanowiły najbardziej ambitne cele krajowe (wyższe niż cel dla UE), ale relacja nakładów na $\mathrm{B}+\mathrm{R}$ do $\mathrm{PKB}$ pogorszyła się w ostatnich latach w tych kra- 
jach. W Polsce obserwowana jest stopniowa poprawa wskaźnika, przy czym jego wartość jest wyraźnie niższa od przeciętnej w UE (w 2014 r. wyniósł 0,94\%, a wartość docelową określono na 1,7\%).

- Przeciwdziałanie niekorzystnym zmianom klimatu i zrównoważone wykorzystanie energii (cele: ograniczenie emisji gazów cieplarnianych o $20 \%$ w porównaniu z 1990 r., zwiększenie udziału energii ze źródeł odnawialnych z zużyciu energii końcowej o 20\%, wzrost efektywności energetycznej o 20\%)

Cele ustanowione w tym obszarze wpisują się w priorytet rozwoju zrównoważonego, który zakłada pobudzanie wzrostu gospodarczego z poszanowaniem środowiska naturalnego. Dotychczasowy okres realizacji strategii przyniósł pozytywne efekty, a czynnikiem sprzyjającym było spowolnienie gospodarcze.

W 2013 r. Wspólnota ograniczyła emisję gazów cieplarnianych o blisko 20\% w porównaniu z 1990 r. Największą redukcję (rzędu 50\%) notowano w krajach bałtyckich i Rumunii, tj. w krajach o niewielkim udziale w całkowitej emisji UE. W Polsce emisja gazów w 2013 r. była niższa o blisko 17\% w porównaniu z $1990 \mathrm{r}$. W siedmiu państwach obserwowano wzrost emisji gazów.

Udział energii ze źródeł odnawialnych w zużyciu energii w UE wzrastał systematycznie i w 2014 r. wyniósł 16\%. We wszystkich państwach członkowskich wykorzystanie energii ze źródeł odnawialnych zwiększyło się w okresie 2009-2014. Istnieje natomiast bardzo duża rozpiętość pomiędzy krajami - od niespełna 5\% w Luksemburgu i na Malcie do ponad 50\% w Szwecji. W Polsce udział energii ze źródeł odnawialnych stopniowo wzrasta i w 2014 r. wynosił 11,4\% końcowego zużycia energii (na 2020 r. założono 15\%).

Stopniowo ograniczane jest zużycie energii pierwotnej w UE - w latach 2009-2014 spadło o ok. 6\%. Na zmniejszanie zużycia, obserwowane w prawie wszystkich krajach, wpływało w tym okresie spowolnienie gospodarcze. W Polsce zużycie energii w 2014 r. było niższe niż w 2009 r. o blisko 1\%.

- Edukacja społeczeństw (cele: zmniejszenie odsetka młodzieży niekontynuującej nauki poniżej 10\%, zwiększenie udziału osób w wieku 30-34 lata posiadających wyższe wykształcenie do $40 \%$ )

Inwestowanie w edukację, a więc w kapitał ludzki, można traktować jako fundamentalne działanie na rzecz pobudzania rozwoju społecznego i gospodarczego. Pięcioletni okres realizacji strategii Europa 2020 wskazuje na pozytywne zmiany.

Odsetek młodzieży niekontynuującej nauki zmniejszył się z 14,2\% populacji UE w 2009 r. do 10,9\% w 2015 r. Postęp obserwowano w większości państw, a połowa osiągnęła już swoje cele krajowe. Polska, ze wskaźnikiem 5,3\%, należy do krajów o najkorzystniejszej sytuacji, natomiast ambitny cel $(4,5 \%)$ nie został jeszcze zrealizowany.

Udział osób posiadających wyższe wykształcenie w UE systematycznie rośnie - w 2015 r. wyniósł 38,5\% i był wyższy niż w 2009 r. o 6,2 pp. Pozytywne tendencje 
obserwowano prawie we wszystkich państwach. W Polsce odsetek osób z wyższym wykształceniem zwiększył się o ponad 10 pp. i wyniósł 43,2\% w 215 r. (przy celu na poziomie $45 \%$ ).

- Przeciwdziałanie ubóstwu i wykluczeniu społecznemu (cel - wydźwignięcie z ubóstwa i wykluczenia społecznego co najmniej $20 \mathrm{mln}$ osób)

Problem ubóstwa i wykluczenia społecznego nasilił się w wyniku kryzysu. Podstawowym wskaźnikiem służącym do monitorowania sytuacji w tym obszarze jest wskaźnik zagrożenia ubóstwem lub wykluczeniem społecznym. Ta miara uwzględnia trzy wskaźniki cząstkowe: wskaźnik pogłębionej deprywacji materialnej, odsetek żyjących w gospodarstwach domowych o bardzo niskiej intensywności pracy oraz odsetek osób zagrożonych ubóstwem po transferach społecznych. Za zagrożoną ubóstwem lub wykluczeniem społecznym jest uznawana osoba, która mieszka w gospodarstwie domowym doświadczającym przynajmniej jednego z trzech elementów.

W 2014 r. 24,4\% ludności Unii Europejskiej było dotkniętych ubóstwem lub wykluczeniem społecznym. To sytuacja gorsza w porównaniu z 2009 r., kiedy odsetek osób zagrożonych ubóstwem wynosił 23,3\%. Liczba ludności zagrożonej ubóstwem i wykluczeniem społecznym wzrosła w analizowanym okresie o blisko 6,5 mln osób. Pomiędzy państwami członkowskimi występuje bardzo duże zróżnicowanie wielkości wskaźnika: od niespełna 15\% w Czechach do ok. 40\% w Bułgarii i Rumunii. W Polsce, odmiennie niż w większości krajów, notowano w tym okresie pozytywne tendencje. Wartości wskaźnika zagrożenia ubóstwem lub wykluczeniem społecznym stopniowo zmniejszały się; w 2009 r. zagrożonych przynajmniej jedną $\mathrm{z}$ trzech form ubóstwa lub wykluczenia było blisko 28\% osób, natomiast w $2014 \mathrm{r}$. wskaźnik wyniósł niespełna $25 \%$. Cel ustanowiony dla naszego kraju, tj. ograniczenie liczby osób zagrożonych ubóstwem o 1,5 mln, został osiągnięty już w 2013 r. ${ }^{1}$

\section{Zakończenie}

Dotychczasowy okres wdrażania strategii Europa 2020 wskazuje, że założone cele są realizowane w różnym stopniu, a kryzys pogłębił zróżnicowanie pomiędzy państwami członkowskimi. Najtrudniejsza sytuacja dotyczy zatrudnienia oraz ubóstwa i wykluczenia społecznego, gdzie szczególnie oddziaływały skutki kryzysu. Problemy widoczne są również w pobudzaniu inwestycji na badania i rozwój, od których zależy poziom efektywności i konkurencyjności gospodarki europejskiej. Pozytywne tendencje rysują się natomiast w obszarze edukacji oraz efektywnego korzystania z zasobów. W przypadku Polski najbardziej problematycznie rysuje się sytuacja w zakresie osiągnięcia założonego wskaźnika nakładów na $\mathrm{B}+\mathrm{R}$ oraz wskaźnika zatrudnienia.

${ }^{1}$ Ta sytuacja nasiliła dyskusje dotyczące przyjętego celu i sposobu pomiaru ubóstwa i wykluczenia społecznego. Jak zauważa prof. Panek, trudności w analizowaniu i ocenie problematyki ubóstwa wynikają przede wszystkim z braku ,precyzyjnej i ogólnie akceptowalnej definicji tego zjawiska" [Panek 2014, s. 195]. 
Biorąc pod uwagę dotychczasowe zmiany w realizacji celów, można postawić pytanie: na ile przyjęcie strategii Europa 2020 miało znaczenie dla obserwowanych zmian? Próba odpowiedzi wymagałaby odrębnej dyskusji, jednak niezależnie od dotychczasowych osiągnięć warto zwrócić uwagę na rolę strategii w funkcjonowaniu UE. Europa 2020 pełni funkcję porządkującą w aktualnym modelu zarządzania gospodarczego. Jej szczególne znaczenie sprowadza się do wyznaczaniu wspólnych kierunków interwencji, planowanych na poziomie europejskim, krajowym oraz regionalnym i lokalnym. Przewodniczący Komitetu Regionów Ramón Luis Valcárcel Siso porównał przyjęcie Europy 2020 do powstania wspólnego języka [Trzecie sprawozdanie... 2012, s. 3], który inicjuje współpracę i partnerstwo. Konsultacje publiczne, przeprowadzone na półmetku realizacji strategii, potwierdziły jej postrzeganie przez różne środowiska jako ważne, nadrzędne ramy dla działań wspierających wzrost gospodarczy i zatrudnienie [Wyniki konsultacji publicznych... 2015, s. 2].

Pobudzanie wzrostu gospodarczego i zatrudnienia to fundamentalny warunek dalszego rozwoju, a w rezultacie spójności UE. Powszechne zrozumienie znaczenia strategii Europa 2020 i poparcie społeczne dla jej wdrażania stwarzają przychylne otoczenie dla podejmowania konsekwentnych wysiłków w dążeniu do spójnych priorytetów. Powiązanie polityki spójności z celami Europy 2020 będzie sprzyjało postępom we wdrażaniu założeń strategii.

\section{Literatura}

Eurostat, http://ec.europa.eu/eurostat/data/database (10.03.2016).

Pakt na rzecz wzrostu i zatrudnienia, 2012, Załącznik do Konkluzji Rady Europejskiej, Bruksela, 29.06.2013.

Panek T., 2014, Ubóstwo i wykluczenie społeczne, [w:] Panek T. (red.), Statystyka społeczna, Polskie Wydawnictwo Ekonomiczne, Warszawa.

Trzecie sprawozdanie monitorujące Komitetu Regionów nt. strategii Europa 2020, październik 2012 r. Wyniki konsultacji publicznych w sprawie strategii Europa 2020, Komunikat Komisji do Parlamentu Europejskiego, Rady Europejskiego Komitetu Ekonomiczno-Społecznego i Komitetu Regionów, Bruksela, 2.3.2015 r., COM(2015) 100.

Wpływ czlonkostwa Polski w Unii Europejskiej i realizowanej polityki spójności na rozwój kraju, Ministerstwo Infrastruktury i Rozwoju, Warszawa, kwiecień 2014 r. 